\title{
Influence of Residual Basal Area on Longleaf Pine (Pinus palustris Mill.) First Year Germination and Establishment under Selection Silviculture
}

\author{
Ferhat Kara*, Edward F. Loewenstein \\ School of Forestry and Wildlife Sciences, Auburn University, Auburn, USA \\ Email: ${ }^{*}$ ferhatom@auburn.edu
}

Received 27 November 2014; revised 14 December 2014; accepted 28 December 2014

Academic Editor: Syed Moazzam Nizami, Arid Agriculture University, Pakistan

Copyright (C) 2015 by authors and Scientific Research Publishing Inc.

This work is licensed under the Creative Commons Attribution International License (CC BY). http://creativecommons.org/licenses/by/4.0/

(c) () Open Access

\section{Abstract}

Even-aged silvicultural methods have been successfully used to manage longleaf pine (Pinus palustris Mill.) forests for wood production; however, successful use of uneven-aged methods to manage this ecosystem is less well documented. In this study, the effects of varying levels of residual basal area (RBA) $\left(9.2,13.8\right.$, and $\left.18.4 \mathrm{~m}^{2} \cdot \mathrm{ha}^{-1}\right)$ on longleaf pine germination and establishment under selection silviculture marked using the Proportional-B method were observed. In addition to RBA, photosynthetically active radiation (PAR) was measured, and the relationships between light penetration, germination, and growth were examined. The study found an inverse relationship between RBA and the number of germinants, but the mortality of germinants was not influenced by RBA. PAR also had a significant positive effect on germination, but, did not affect mortality of germinants. In addition, RBA and PAR had no effect on mortality or growth of planted seedlings. Continued monitoring of seedling recruitment into the stand will be required to determine the efficacy of the system. However, nothing in the first year data suggests that this approach will not be successful in sustaining an uneven-aged stand.

\section{Keywords}

Even-Aged, Germinant, Longleaf Pine, Survival, Uneven-Aged

\footnotetext{
"Corresponding author.
}

How to cite this paper: Kara, F., \& Loewenstein, E. F. (2015). Influence of Residual Basal Area on Longleaf Pine (Pinus palustris Mill.) First Year Germination and Establishment under Selection Silviculture. Open Journal of Forestry, 5, 10-20. 


\section{Introduction}

The longleaf pine (Pinus palustris Mill.) ecosystem has historically been very important in the south eastern USA due to its extensive area and high biodiversity. These forests produce high quality timber and usually provide high quality wildlife habitat for many animal species (Brockway et al., 2005). Longleaf pine is tolerant of fire, disease, and insects (Croker \& Boyer, 1975). It is thought to have occupied up to 38 million hectares in the south eastern USA prior to European settlement (Frost, 1993). Frequent disturbance across this region, especially fire, contributed this species' dominance (Chapman, 1932), and also created an irregular, uneven-aged structure across the landscape. However, with the arrival of European settlers, exploitation of longleaf pine forests began in the early 1700's (Outcalt, 2000), and large areas of longleaf pine were cleared without concern for regeneration. As a result, approximately $97 \%$ of these forests were lost to agriculture or to dominance by other species such as loblolly pine (Pinus taeda L.). Only 1.2 million hectares of longleaf pine forests remained by 1995 (Brockway et al., 2005). The longleaf pine forest type is now considered an ecosystem at high risk in the USA (Frost, 2006).

With an increasing awareness of the economic, ecological, and social values provided by this ecosystem, there has been a growing interest in the restoration of this forest type and in the management of longleaf pine forests that remain (Guldin, 2006). Beginning in the 1950's, silvicultural studies focused on restoration and regeneration of longleaf pine using even-aged silvicultural methods including clearcutting, seed-tree and shelterwood (Gagnon et al., 2003). These techniques were considered to be the logical and appropriate approach to the regeneration problem, given that longleaf pine is a shade and competition intolerant species (Boyer, 1990). Of those early studies, the shelterwood trials were particularly successful, and have been used since that time to regenerate the species (Croker \& Boyer, 1975). The shelterwood system allows for continued production of high quality timber; unfortunately, complete overstory removal at the end of the rotation has been shown to have a negative impact on the ecological functions and values provided by the longleaf pine forest (Brockway et al., 2006). Even-aged regeneration harvests impact the rich animal and plant diversity, typical of the natural longleaf system, and this diversity has not fully recovered over the length of typical 50-year rotation. As a result, some animal and plant species associated with the natural longleaf ecosystem have become rare (Van Lear et al., 2005). However, it should be noted that even-aged methods with extended rotations may provide many of the same ecological benefits derived from natural stands. Long rotations may provide suitable conditions for some wildlife and plant species (Nyland, 2002), ensure a greater flexibility and ease in management, bring higher economic returns by growing more valuable, large dimater trees, enhance aesthetic values (Nyland, 2002), and increase carbon sequestration (Foster et al., 2010).

Even though uneven-aged methods may seem to be more appropriate than traditional even-aged methods for the restoration of the rich animal and understory plant diversity in the longleaf pine ecosystem (Brockway \& Outcalt, 1998; Brockway et al., 2005), some scientists and forest managers have suggested that selection systems are impractical in these forests because regeneration of the species will be hindered by its intolerance to shade and competition (Croker \& Boyer, 1975). On the other hand, the uneven-aged mosaic of small even-aged groups that were present in natural longleaf forests (Brockway \& Outcalt, 1998) suggests that selection methods should be successful if we can determine the appropriate type, timing and intensity of disturbance needed to mimic that which historically occurred in these forests.

We believe that residual basal area (RBA) may be one important factor in longleaf pine germination and establishment. Several studies have helped to determine upper and lower limits of basal area $\left(6.9\right.$ and $4.6 \mathrm{~m}^{2} \cdot \mathrm{ha}^{-1}$, respectively) needed to obtain an adequate number of established seedlings using the shelterwood method (Boyer, 1993; Croker \& Boyer, 1975). However, similar studies for uneven-aged silviculture have not been undertaken. Further, it is unlikely that the RBA limits determined for even-aged stands are also applicable for uneven-aged management of longleaf pine, given that the overstory is never completely removed and recruitment requirements are substantially lower because the stand is not being replaced by a single cohort of reproduction at one point in time.

In this study, we examine the effects of varying levels of RBA $\left(9.2,13.8\right.$, and $\left.18.4 \mathrm{~m}^{2} \cdot \mathrm{ha}^{-1}\right)$ on longleaf pine germination and establishment under single-tree selection silviculture managed using the Proportional-B method (Loewenstein, 2005; Brockway et al., 2014). Our hypothesis is that establishment of longleaf pine seedling increases with decreasing overstory density. We further hypothesize that adequate numbers of seedlings can be established under higher levels of RBA than the upper limit suggested for shelterwood. 


\section{Methodology}

\subsection{Study Site}

The study was conducted on the Escambia Experimental Forest (EEF) $\left(31^{\circ} 01^{\prime} \mathrm{N}, 87^{\circ} 04^{\prime} \mathrm{W}\right)$ which is located 11 $\mathrm{km}$ south of Brewton, Alabama, in the southeastern USA (Figure 1). EEF is located within the middle Coastal Plain site. This 1214 hectare forest was established in 1947 to study the ecology and management of longleaf pine forests. About $80 \%$ of the forest is dominated by longleaf pine, and the remainder consists of slash pine (Pinus elliotti Engelm.) and mixed hardwoods. EEF can be characterized as an open canopy of longleaf pine with a rich understory. A variety of shrub oaks occupies the midstory while understory usually consists of grasses, forbs, shrubs, and vines. Grasses such as wiregrass (Aristida spp.) and Bluestem grasses (Andropogon spp.) are the predominant ground cover. Average site index for longleaf pine is about $21-23 \mathrm{~m}$ (base age 50). Soils are coarse to fine, loamy, siliceous thermic Paleudults (Adams et al., 2003). The predominant soil type on the forest is Troup fine sand. The climate is mild and humid, bordering on subtropical. Annual precipitation is about $1520 \mathrm{~mm}$, and average range of temperature is $-7^{\circ} \mathrm{C}$ to $37^{\circ} \mathrm{C}$ (Adams et al., 2003). Elevation ranges from about 30 to $87 \mathrm{~m}$ above sea level. Topography is flat to rolling, and most slopes are in the range of $3 \%$ to $10 \%$.

\subsection{Statistical Analysis}

The study was laid out as a completely randomized design. In the winter of 2010, nine 2-hectare square plots were established, and randomly assigned to one of three levels of RBA; 9.2, 13.8, $18.4 \mathrm{~m}^{2} \cdot \mathrm{ha}^{-1}(40,60,80$ $\mathrm{ft}^{2} \cdot \mathrm{ac}^{-1}$ respectively). It was possible to conduct statistical analyses with the plots as the experimental unit. Each treatment was replicated three times. Assigned treatments were applied to the entire plot. Treatment response was estimated by subsampling. Each study plot included six $\left(100 \mathrm{~m}^{2}\right)$ square overstory measurement subplots, and eighteen $\left(10 \mathrm{~m}^{2}\right)$ circular understory subplots (Figure 2). Overstory and understory subplots were systematically located within each plot (Figure 2).

Simple linear regression was used to test the relationships between RBA and 1) the number of germinants, 2) survival of germinants, 3) survival of planted seedlings, 4) growth of planted seedlings, and 5) diameter increment of overstory trees. Statistical significance was determined at $\alpha=0.05$. R-Statistical software was used for the analyses. To test the effect of initial BA and its interaction with RBA on germination, a multiple regression model was performed using General Linear Model (GLM) of the R-Statistical software.

A wildfire occurred on one of the mid-level BA plots, $\mathrm{M}_{2},\left(13.8 \mathrm{~m}^{2} \cdot \mathrm{ha}^{-1}\right)$ before the first growing season

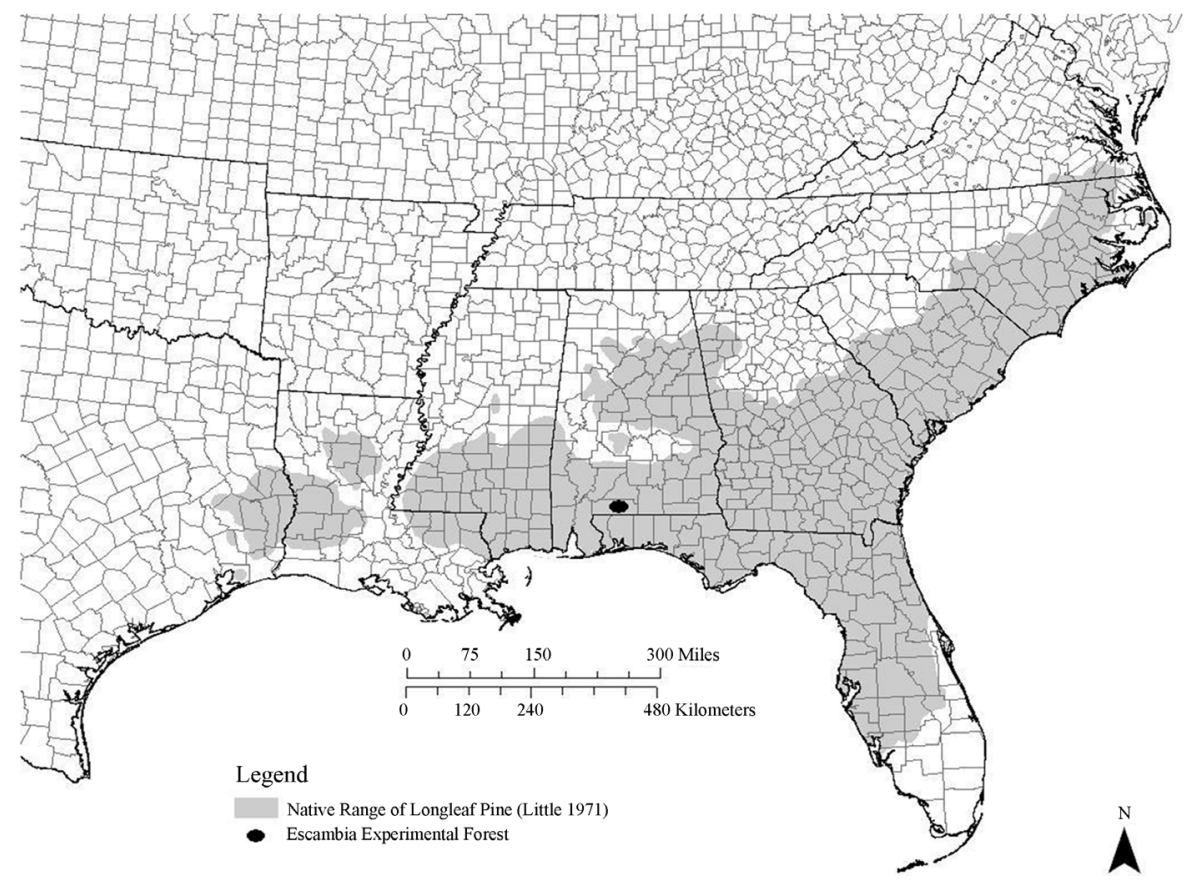

Figure 1. Location of the Escambia experimental forest within the Longleaf Pine natural range (Little, 1971). 


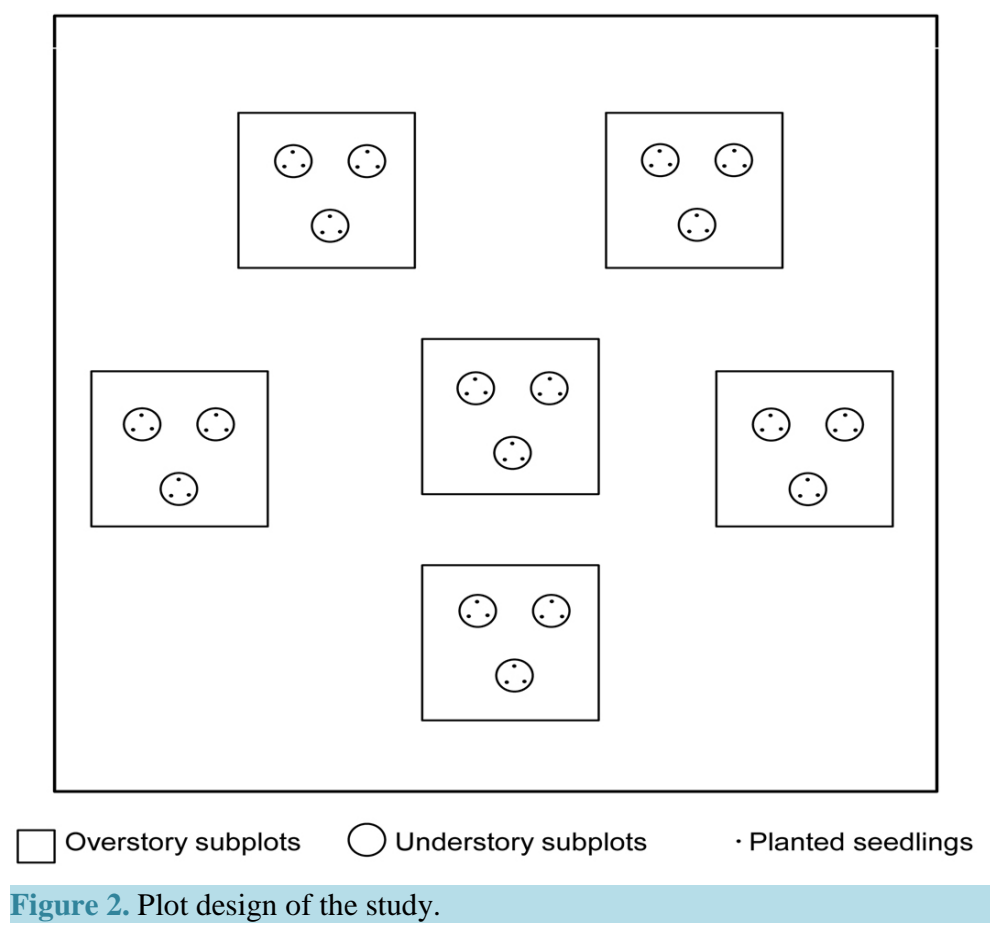

(May $21^{\text {st }}$, 2012), all of the new germinants were consumed, and thus, data from this plot was not included in the analysis of subsequent measurement periods.

\subsection{Harvesting}

Harvest operations were completed during the first week of May, 2011. Stands were marked to the defined treatment RBA using single tree-selection based on the Proportional-B method (Pro-B). Pro-B is an uneven-aged marking approach that is loosely based on structural control and allows one-pass marking of a stand (Brockway et al., 2014). We used a standard "target structure" defined by a q-value of 1.3 (for $5 \mathrm{~cm}$ diameter class) and a largest diameter tree (LDT) of $46 \mathrm{~cm}$. This structure has its BA distributed among three product classes $(<15$ $\mathrm{cm} ; 15-30 \mathrm{~cm} ;>30 \mathrm{~cm}$ ) in a ratio of approximately 1:2:3 (Loewenstein, 2005). Maintaining this distribution ensures a continuous canopy cover, maintains full site utilization with approximately $80 \%$ of stand BA allocated to the sawtimber size classes. In addition, in studies with longleaf pine and with other intolerant and moderately shade intolerant species (Loewenstein, 2005), it has been shown that the distribution allows sufficient growing space for the recruitment of new cohorts as needed.

\subsection{Prescribed Fire}

Longleaf pine has a unique and distinctive phase of development called the "grass stage". Following germination, young longleaf pine seedlings undergo an extended phase without height growth during which time they build an extensive root system. During this phase, the seedling closely resembles a clump of grass (Brockway et al., 2006). In the grass stage, longleaf pine has no stem or cambium. Its large needles surround the terminal bud and by quickly developing a thick bark and large root system, longleaf pine becomes tolerant of fire beginning within a year of germination. This fire adaptation benefits longleaf pine in several ways. Germination of longleaf seed is facilitated on exposed mineral soil, thus, frequent fire is a disturbance that removes the litter layer and prepares the seedbed (Brockway et al., 2006). Since longleaf pine is competition intolerant, the control of hardwood sprouts and other woody species that is observed with repeated fire is considered essential to ensure seedling establishment (Boyer, 1993). Further, regular fire while longleaf is in the "grass stage" controls brownspot needle blight (caused by a fungus called Scirrhia acicola) which can be a destructive pathogen of longleaf seedlings in the absence of fire (Chapman, 1932).

Study plots were burned in the first week of September, 2011, following harvest and prior to seed dispersal, in 
order to reduce competition and expose the mineral soil. Burning during this time of the year is not common due to the potential damage to overstory trees. However, our prescription for the prescribed fire was tightly controlled to minimize these risks while addressing our primary intent to eliminate hardwood sprouts and other woody plants, and prepare the seedbed before seed dispersal of longleaf pine, which occurs in late October. No damage to the overstory trees was evident following the prescribed fire.

\subsection{Planting}

The focus of this study is on natural regeneration. However, since longleaf pine exhibits a high degree of annual variation in seed production, producing only sporadic and irregular cone crops, we decided to plant seedlings in the event that seed production was poor or failed during 2011-2012. Three longleaf seedlings were planted in each regeneration subplot (486 in total) in early December, 2011, following the previously described prescribed fires. Seedlings were $15-\mathrm{cm}$ deep-plug containerized seedlings with a rooting volume of $100 \mathrm{~cm}^{3}$. They were planted approximately $1 \mathrm{~m}$ away from plot center and equidistant from each other to minimize the competition with each other (Figure 2). Seedlings were tagged and numbered after planting to monitor growth and survival.

\subsection{Measurements}

Overstory trees ( $>10 \mathrm{~cm}$ in diameter) were tagged in the $100 \mathrm{~m}^{2}$ overstory subplots, diameter at breast height (DBH) measured at $1.4 \mathrm{~m}$ above the ground, was measured in December 2010 before the treatments were imposed and again in July 2012 during the first measurement period. The diameter increment of overstory trees was calculated as the difference between the July 2012 and December 2010 measurements.

New germinants were tallied on each of the regeneration subplots and individually flagged in January 2012. Unlike other southern pines that germinate in the spring, longleaf pine seeds germinate less than a week after dispersal and do not remain viable beyond that time (Boyer, 1990). Seed dispersion of longleaf pine occurs in late October; no additional germination was observed between January 2012 and the July 2012 re-measurement. Germinants flagged in January 2012 were tallied again in July 2012 to monitor survival. For the seedlings that were planted in the regeneration subplots, initial root collar diameter (RCD) was recorded soon after the planting (January 2012). RCD, which is the diameter of the seedling at the base of the main stem, was measured to the nearest millimeter using a digital caliber. RCD measurements were repeated in the first growing season (July 2012) to calculate growth of planted seedlings. Mortality of planted seedlings was also recorded at that time.

Photosynthetically active radiation (PAR) was measured under the canopy, on nearly cloudless days between 11:00 am and 2:00 pm (July 2012). Readings were taken $1.25 \mathrm{~m}$ above the ground at the center of each regeneration subplot using an AccuPar Linear PAR/LAI Model PAR-80 ceptometer (Decagon Devices, Inc., Pullman, WA, 2011). The ceptometer was leveled during measurement, and special care was taken to prevent the operator's shadow from falling across the sensors. The ceptometer averages readings of 80 individual sensors along a 0.8 meter array. A total of 5 readings were taken at the center of each regeneration subplot (90 readings on each 2-ha plot). In addition, a continuous reading (observations recorded every $15 \mathrm{sec}$ ) HOBO weather station PAR sensor (Onset Computer Corporation, 2009) was installed in an adjacent treeless area. Light transmittance through the canopy was calculated using the following formula;

PAR Transmittance $=($ PAR under canopy $/$ PAR in open $) * 100$.

\section{Results and Discussion}

\subsection{Overstory}

Following harvest, measured RBA was fairly close to our target RBA on most plots $(p<0.05)$ (Table 1$)$. The greatest deviation from the target BA was $+1.8 \mathrm{~m}^{2} \cdot \mathrm{ha}^{-1}$ and $-1.2 \mathrm{~m}^{2} \cdot \mathrm{ha}^{-1}$ on two of the low-BA plots $(-12.9$ and $+17.1 \%$ respectively). One additional plot was off target by $0.9 \mathrm{~m}^{2} \cdot \mathrm{ha}^{-1}(+6.2 \%)$, the remainder of the plots were within $5 \%$ of the target. The large deviations in the two low-BA plots were probably due to the presence of large diameter trees. Missing even one large marked tree, or cutting one large unmarked tree during harvesting results in substantial deviation from the target.

Light penetration ranged from $22 \%$ to $43 \%$ across all plots. There was a statistically significant, inverse relationship between BA and PAR post-harvest $(p=0.0025)$ (Figure 3(a)). There was also a significant relationship 


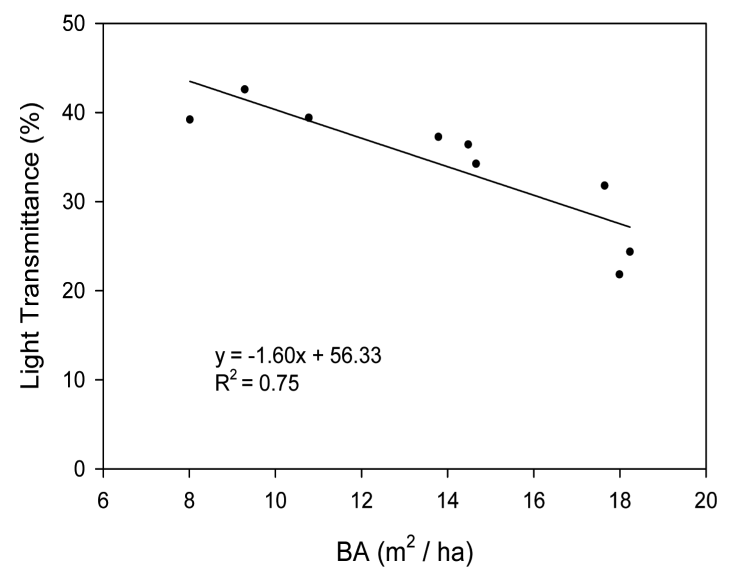

(a)

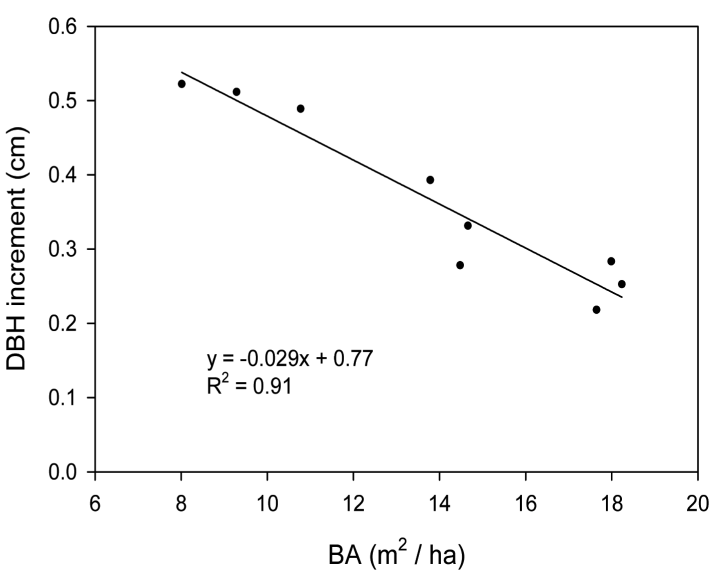

(b)

Figure 3. Relationships between BA and (a) Light transmittance; (b) Diameter increment in the first growing season.

Table 1. Summary of the harvesting in each plot.

\begin{tabular}{ccccc}
\hline Plot & Initial BA $\left(\mathrm{m}^{2} \cdot \mathrm{ha}^{-1}\right)$ & $\begin{array}{c}\text { Target BA } \\
\left(\mathrm{m}^{2} \cdot \mathrm{ha}^{-1}\right)\end{array}$ & $\begin{array}{c}\text { Final BA } \\
\left(\mathrm{m}^{2} \cdot \mathrm{ha}^{-1}\right)\end{array}$ & Deviation from the target BA (\%) \\
\hline $\mathrm{H}_{1}$ & 30 & 18.4 & 17.6 & -4.1 \\
$\mathrm{H}_{2}$ & 29.8 & 18.4 & 18.2 & -0.9 \\
$\mathrm{H}_{3}$ & 21.8 & 18.4 & 18.0 & -2.2 \\
$\mathrm{M}_{1}$ & 24.9 & 13.8 & 14.7 & +6.2 \\
$\mathrm{M}_{2}$ & 29.6 & 13.8 & 14.5 & +4.9 \\
$\mathrm{M}_{3}$ & 19.2 & 13.8 & 13.8 & 0.0 \\
$\mathrm{~L}_{1}$ & 11.5 & 9.2 & 8.0 & -12.9 \\
$\mathrm{~L}_{2}$ & 13.7 & 9.2 & 9.3 & +1.0 \\
$\mathrm{~L}_{3}$ & 15.9 & 9.2 & 10.8 & +17.1 \\
\hline
\end{tabular}

between diameter increment of overstory trees and both BA $(p<0.0001)$ (Figure 3(b)), and PAR $(p=0.015)$ in the first year following harvest. Average diameter growth ranged from 0.22 to $0.52 \mathrm{~cm}$ across all plots with diameter growth higher on low BA plots.

\subsection{Germination}

There was a statistically significant, inverse relationship between the number of germinants and RBA $(p=0.016)$ following harvest (Figure 4(a)). The average number of germinants ranged from 11,000 to 88,000 per hectare across all plots. We speculate that this relationship is primarily due to higher levels of light penetration to the ground with decreasing RBA across the plots, rather than the amount of tree removal or soil disturbance caused by logging and skidding operations in the plots. Note that, in the two most heavily harvested plots where BA was reduced by around $40 \%$, the number of germinant was still lowest. These were high RBA plots where the light penetration was still relatively less in spite of the higher intensity of tree removal. Also recall that a prescribed fire was applied in advance of seedfall to prepare an exposed mineral soil seedbed. It is unlikely that the additional disturbance caused by harvesting operations was necessary to further improve conditions for germination.

As can be seen in Figure 4(a), one of the mid-level BA plots, $\mathrm{M}_{1},\left(13.8 \mathrm{~m}^{2} \cdot \mathrm{ha}^{-1}\right)$ had a large number of germinants, and seems to be an outlier. Despite our efforts to install the plots in a block and away from roads, this specific plot was located at an intersection of two forest roads. As previously stated, cone production of longleaf pine decreases with increasing overstory density (Croker \& Boyer, 1975). We believe that the trees along the 


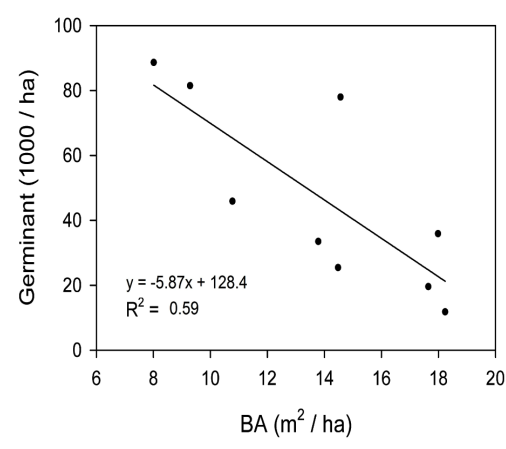

(a)

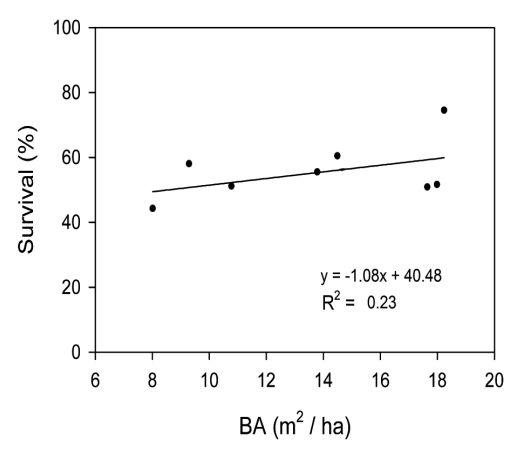

(b)

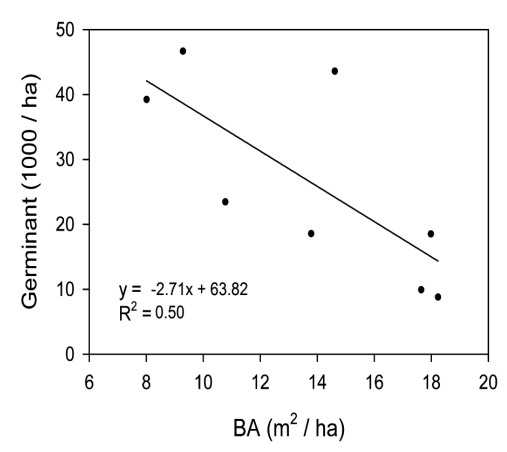

(c)

Figure 4. Relationships between BA and (a) Number of germinant during the germination period; (b) Survival of germinant in the first growing season; (c) Number of germinant in the first growing season.

roads had relatively greater amounts of growing space, developed larger crowns, produced more cone and seeds, and this consequently increased number of germinants in this specific plot. The roads were also likely responsible for the relatively greater light penetration in this stand. Regression equations both with and without the outlier were fit and their slopes were compared. The slopes were not statistically different for the first year germinant-RBA relationship ( $p=0.89$ ), for the germinant survival-RBA relationship ( $p=0.99)$, for the second year germinant-RBA relationship ( $p=0.88$ ), for the survival of planted seedlings-RBA relationship $(p=0.94)$, or for RCD growth-RBA relationship $(p=0.88)$. Although removal of outlier did not significantly change the regression slopes, its removal would substantially increase R-square values and decrease p-values. However, it is also possible that this data point may simply be within the inherent range of variability in these stands. Thus, it was retained in the analysis.

Longleaf pine is a sporadic and typically poor seed producer. Good seed crops are irregular and occur at 5 to 7 year intervals (Boyer, 1990). Based on the 2011 cone crop report for longleaf pine (Brockway \& Boyer, 2012), we were fortunate to have initiated this study during a good seed year. Our cultural operations were designed to maximize seedling establishment regardless of the cone crop. Harvest operations were performed prior to seed dispersal in order to increase success. As longleaf pine germinates immediately following seed dispersal, even a short delay in the harvest would have had an adverse effect on initial establishment due to mechanical disturbance of the new germinants and a poor light environment at the time of germination. In addition, as previously stated, germination of longleaf pine seed requires exposed mineral soil. This is often accomplished using prescribed fire and in its absence, the large seed and wing may not reach the soil because of dense grass or accumulated litter (Brockway et al., 2006). By using a growing season fire, our primary objectives were to expose mineral soil, control other woody species, and prepare the seed bed shortly before seed dispersal. Our germination results suggest both good planning and good fortune. Even so, it is important to understand that we were able to apply a growing season fire only because these study plots have been regularly burned in the past; none of them had more than 3.5 years of fuel accumulation at the time of the burn. For stands that have not been burned for a prolonged period, growing season prescribed fire is not commonly used because of the increased risk of mortality to the overstory trees. We observed no fire induced mortality of overstory trees on our study plots so far.

Our harvest operations were conducted in May and were designed and timed to influence germination. This treatment would not have affected cone production in that year because it was initiated after the emergence of conelet buds which occurs in January or February (Boyer, 1990). However, because stand density is known to impact cone production in longleaf pine (Croker \& Boyer, 1975) and consequently may influence the number of germinants, and because pre-harvest BA on the study plots ranged from 11.5 to $30 \mathrm{~m}^{2} \cdot \mathrm{ha}^{-1}$ (Table 1 ), we used multiple regression to determine whether initial BA may have confounded our results. There were no statistically significant effect of initial BA on the number of germinants $(p=0.94)$ nor were there an affect from the interaction of initial BA with RBA on the number of germinants ( $p=0.93$ ).

\subsection{Mortality}

Mortality of germinants was not affected by either RBA $(p=0.22)$ or PAR $(p=0.24)$ during the first growing 
season (Figure 4(b)). Average survival was approximately 55\% across all plots with a single exception; one plot $\left(\mathrm{M}_{2}\right)$ had $75 \%$ survival. Survival of longleaf germinants is lowest during the first year (Brockway et al., 2006) with mortality attributed to factors including: seed predation, disease, grazing, drought, flooding, and frost (Croker \& Boyer, 1975; Boyer, 1993). Brockway et al. (2006) stated that first year mortality of $50 \%$ is common during the spring drought period. In addition, it is known that new longleaf seedlings may remain and survive in its well-known grass stage for up to 15 years, even under overstories ranging up to $21 \mathrm{~m}^{2} \cdot \mathrm{ha}^{-1}$ (Coker \& Boyer, 1975; Boyer, 1993). Our observations were consistent with previous studies; mortality of longleaf seedlings is not related to overstory density in the absence of fire (Boyer, 1963; Palik et al., 1997). Instead, root competition is more responsible for seedling mortality (McGuire et al., 2001).

There was a statistically significant relationship between the number of germinants and RBA in the first growing season (July 2012) $(p=0.048)$ (Figure 4(c)). In addition, a significant relationship between PAR and number of germinants was observed $(p=0.034)$. Despite the approximate $45 \%$ mortality that occurred during the first year, there are still large numbers of germinants, even under the high RBA plots. The number of seedlings in the first growing season ranged from 8000 to 46,000 seedlings per hectare. Although survival is lowest during the first year following germination (Brockway et al., 2006), Boyer (1963) states that subsequent survival of one-year old seedlings ranged from 65 to 80 percent through age 7. If the mortality of our germinants follows a similar trend, then we should have at least 7000 seedlings per hectare in any plot by age 7 , and this conservatively assumes that no additional germinants would be recruited during this time period. Further, if we project seedling establishment only during a good seed crop and use the high end of the published interval of 5 - 7 years between good crops (Wahlenberg, 1946; Boyer, 1990); in addition, if we assume that all grass stage seedlings die by age 15 (Brockway et al., 2006), another conservative assumption, there should still always be at least two cohorts of seedlings on site. This would continuously maintain an adequate seedling bank available for recruitment into the stand whenever conditions were conducive for release.

\subsection{Planted Seedlings}

In the first year following planting, there was no significant relationship between RBA and mortality of planted seedlings $(p=0.84)$ (Figure 5(a)). Survival ranged from 93\% to 100\% across all plots. As we observed, several studies have shown that seedling survival is not influenced by overstory density in longleaf pine forests (Boyer, 1993; Palik et al., 1997; Gagnon et al., 2003), and planted seedlings may survive under parent overstory for up to 8 years or longer (Croker \& Boyer, 1975; Boyer, 1990). In addition, RBA and PAR did not significantly affect RCD growth of planted seedlings in the first growing season $(p=0.99)$ (Figure 5(b)). Average RCD growth of seedlings ranged from 1.04 to $2.06 \mathrm{~mm}$ across all plots. Although it has been shown that early growth of longleaf seedlings is quite slow, even under low levels of overstory RBA (Boyer, 1993), it is usually expected that higher RCD growth would be observed under low RBA (Palik et al., 1997). Gagnon et al. (2003) found that longleaf seedling growth was positively correlated with light transmittance. We believe that the lack of statistical insignificance between RBA and RCD growth may be due to transplant shock in the first year following planting. RCD measurement will be monitored into the future so that we can determine whether light levels will be positively correlated with seedling growth following establishment. Although we will continue to monitor seedling development given the initial data, we believe that under-planting of longleaf pine seedlings appears to be an option where species conversion is an objective, or where enrichment planting is needed.

\subsection{Sustainable Recruitment}

Given the substantial seedling bank that was created on site across the range of RBA examined in this study, the next logical question is whether these stand conditions are suitable to provide sustained recruitment into the overstory. Existing research provide some evidence as to whether the current seedling bank is adequate to regenerate the stand using the commonly successful shelterwood method. Croker \& Boyer (1975) suggest that 1250 longleaf seedlings per hectare in height growth, within 6 years of release following shelterwood removal, are the criteria for successful regeneration. In order to obtain these numbers, they recommend between 10500 and 17,250 well established seedlings per hectare at the time of release. Since all overstory trees are removed at the time of release (the removal cut under a shelterwood system), the seed source is gone which precludes additional germination. Thus, an excessive number of seedlings are needed under even-aged methods because no replacement is likely in the event of seedling mortality. It is noteworthy that even under these conservative even-aged 


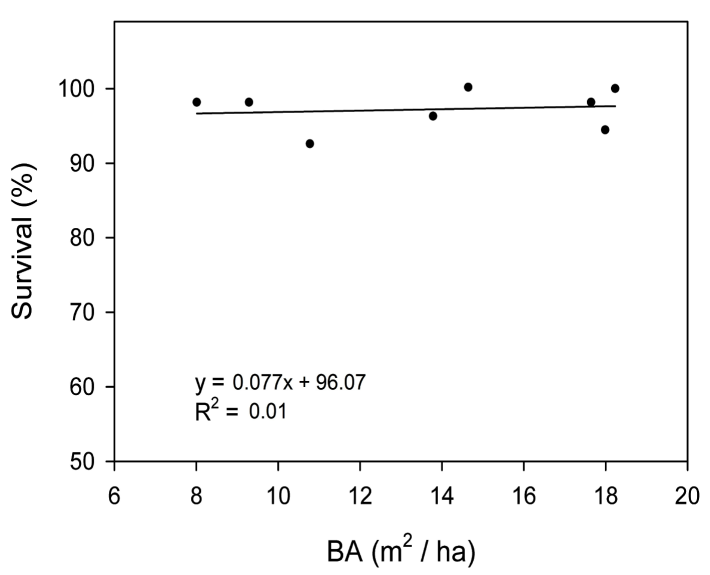

(a)

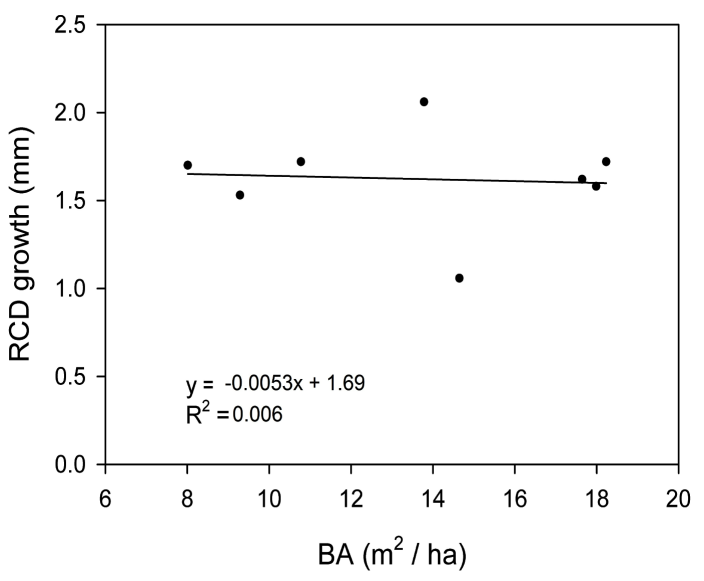

(b)

Figure 5. Relationships between BA and (a) Survival of planted seedlings; (b) RCD growth of planted seedlings in the first growing season.

criteria, most of our research plots already contain sufficient well established seedlings to succeed following complete release.

However, such conservative criteria should not necessarily be required under an uneven-aged scenario. Our target stand structures that were created based on the Pro-B method show that a much smaller number of seedlings are required in the smallest diameter class $(0-5 \mathrm{~cm}$ in $\mathrm{DBH})$ ranging from only 71 to 145 seedlings per hectare depending on RBA. Assuming 65\% survival to year 7 (Boyer, 1965), we project more than 7000 seedlings per hectare at that time; thus, only a small fraction of these seedlings must be recruited into the stand to maintain a stable diameter structure. Again, the question becomes at what rate must seedlings be recruited into the $0-5 \mathrm{~cm}$ diameter class to replace those lost to mortality and upgrowth into the next larger size class? We cannot yet predict the rate of seedling development under our range of RBAs, when (or if) any of these seedling begin height growth, or if they do, how many will be recruited into the stand. We do expect that due to the gapped and patchy nature of a longleaf pine stand, further exacerbated by the periodic removal of trees under a selection system, that if and when height growth of seedlings is initiated it will occur only where these seedlings obtain adequate light while those under a more dense portion of the stand will not recruit. Our current study is well designed to eventually answer these questions. Thorough continued monitoring of survival and growth of seedlings as well as the episodic recruitment of new germinants, we should be able to identify a range of stand density, disturbance frequency and intensity that will recruit sufficient seedlings into the stand to ensure sustainability.

\section{Conclusion}

Although concern over the restoration of longleaf pine forests has increased in recent years, practical methods to accomplish this goal are still needed. Even-aged methods, especially shelterwood, have proven successful in longleaf pine regeneration for timber production. Even-aged methods with a long rotation may offer additional benefits such as restoration, wildlife, carbon storage, species diversity, aesthetics, and recreation. We believe that if sufficient research demonstrates the success of uneven-aged methods in longleaf pine forests, these methods may be an alternative to even-aged methods in some situations where they might better fulfill a landowner's objectives. This study presents the initial (first year) results of using an uneven-aged method to regenerate longleaf pine. We observed that the number of germinants was inversely related to RBA. However, RBA did not affect the mortality of new germinants over the course of the first growing season. In addition, RBA did not influence mortality or growth of planted seedlings during the first year. Although we cannot yet predict the number of seedlings that will be recruited into the stand or whether recruitment will be affected by RBA, given the mortality rates reported in the literature (Boyer 1963), we may already have more than an adequate number of germinants in most of the study plots. Continued measurements are required to determine the efficacy of single-tree selection in longleaf pine forests. Present data are not yet sufficient to address recruitment into the overstory. 


\section{Acknowledgements}

We thank Dale Brockway, David Dyson and Ronald Tucker for their assistance with fieldwork, and USDA Forest Service, Southern Research Station for their support of this research. We also acknowledge the Turkish Ministry of National Education for provision of a PhD scholarship to the first author.

\section{References}

Adams, M. B., Loughry, L., \& Plaugher, L. (2003). Experimental Forests and Ranges of the USDA Forest Service. Newton Square, PA: USDA Forest Service Publication.

Boyer, W. D. (1963). Development of Longleaf Pine Seedlings under Parent Trees. New Orleans, LA: USDA Forest Service Publication.

Boyer, W. D. (1990). Pinus palustris Mill. Longleaf Pine. In R. M. Burns, \& B. H. Honkala (Eds.), Silvics of North America (pp. 405-412). Washington DC: USDA Forest Service Publication.

Boyer, W. D. (1993). Regenerating Longleaf Pine with Natural Seeding. In S. M. Hermann (Ed.), Proceeding of the 18th Tall Timbers Fire Ecology Conference, 30 May-2 June 1991, Tallahassee, 299-303.

Brockway, D. G., \& Boyer, B. (2012). Longleaf Pine Cone Prospects for 2011 and 2012. Brewton, AL: Escambia Experimental Forest Office.

Brockway, D. G., \& Outcalt, K. W. (1998). Gap-Phase Regeneration in Longleaf Pine Wiregrass Ecosystems. Forest Ecology and Management, 106, 125-139. http://dx.doi.org/10.1016/S0378-1127(97)00308-3

Brockway, D. G., Loewenstein, E. F., \& Outcalt, K. W. (2014). Proportional Basal Area Method for Implementing Selection Silviculture Systems in Longleaf Pine Forests. Canadian Journal of Forest Research, 44, 977-985. http://dx.doi.org/10.1139/cjfr-2013-0510

Brockway, D. G., Outcalt, K. W., \& Boyer, W. D. (2006). Longleaf Pine Regeneration Ecology and Methods. In S. Jose, E. J. Jokela, \& D. L. Miller (Eds.), The Longleaf Pine Ecosystem: Ecology, Silviculture, and Restoration (pp. 95-133). New York, NY: Springer. http://dx.doi.org/10.1007/978-0-387-30687-2_4

Brockway, D. G., Outcalt, K. W., Tomczak, D. J., \& Johnson, E. E. (2005). Restoration of Longleaf Pine Ecosystems. Asheville, NC: USDA Forest Service Publication.

Chapman, H. H. (1932). Is the Longleaf Type a Climax? Journal of Ecology, 13, 328-334. http://dx.doi.org/10.2307/1932309

Croker, T. C., \& Boyer, W. D. (1975). Regenerating Longleaf Pine Naturally. New Orleans, LA: USDA Forest Service Publication.

Decagon Devices, Inc., Pullman, WA. AccuPAR PAR/LAI Ceptometer (2011). Operator’s Manual. http://manuals.decagon.com/Manuals/10242_Accupar\%20LP80_Web.pdf

Foster, B. C., Robards, T. A., \& Keeton, W. S. (2010). Carbon Dynamics Associated with Even-Aged Forest Management. Climate Action Reserve (CAR). http://www.climateactionreserve.org/

Frost, C. C. (1993). Four Centuries of Changing Landscape Patterns in the Longleaf Pine Ecosystem. Proceedings of the 18th Tall Timbers Fire Ecology Conference, Tallahassee, 30 May-2 June 1991, 299-303.

Frost, C. C. (2006). History and Future of the Longleaf Pine Ecosystem. In S. Jose, E. J. Jokela, \& D. L. Miller (Eds.), The Longleaf Pine Ecosystem: Ecology, Silviculture, and Restoration (pp. 217-251). New York: Springer.

http://dx.doi.org/10.1007/978-0-387-30687-2_2

Gagnon, J. L., Jokela, E. J., Moser, W. K., \& Huber, D. A. (2003). Dynamics of Artificial Regeneration in Gaps within a Longleaf Pine Flatwoods Ecosystem. Forest Ecology and Management, 172, 133-144. http://dx.doi.org/10.1016/S0378-1127(01)00808-8

Guldin, J. M. (2006). Longleaf Pine Regeneration Ecology and Methods. In S. Jose, E. J. Jokela, \& D. L. Miller (Eds.), The Longleaf Pine Ecosystem: Ecology, Silviculture, and Restoration (pp. 217-251). New York: Springer. http://dx.doi.org/10.1007/978-0-387-30687-2_7

Little Jr., E. L. (1971). Atlas of United States Trees, Volume 1. Conifers and Important Hardwoods. US Department of Agriculture, Forest Service, Msc. Publication No. 1146. 9p+Maps.

Loewenstein, E. F. (2005). Conversion of Uniform Broadleaved Stands to an Uneven-Aged Structure. Forest Ecology and Management, 215, 103-112. http://dx.doi.org/10.1016/j.foreco.2005.05.007

McGuire, J. P., Mitchell, R. J., Moser, E. B., Pecot, S. D., Gjerstad, D. H., \& Hedman, C. W. (2001). Gaps in a Gappy Forest: Plant Resources, Longleaf Pine Regeneration, and Understory Response to Tree Removal in Longleaf Pine Savannas. Canadian Journal of Forest Research, 31, 765-778. http://dx.doi.org/10.1139/x01-003

Nyland, R. D. (2002). Silviculture, Concepts and Applications (2nd ed.). Long Grove, IL: Waveland Press, Inc. 
Onset Computer Corporation (2009). HOBO ${ }^{\circledR}$ Weather Station User’s Guide. http://www.onsetcomp.com/files/manual_pdfs/6106-I-MAN-H21.pdf

Outcalt, K. W. (2000). The Longleaf Pine Ecosystem of the South. Native Plant Journal, 1, 42-53.

Palik, B. J., Mitchell, R. J., Houseal, G., \& Pederson, N. (1997). Effects of Canopy Structure on Resource Availability and Seedling Responses in a Longleaf Pine Ecosystem. Canadian Journal of Forest Research, 27, 1458-1464. http://dx.doi.org/10.1139/x97-081

Van Lear, D. H., Carroll, W. D., Kapeluck, P. R., \& Johnson, R. (2005). History and Restoration of the Longleaf PineGrassland Ecosystem: Implications for Species at Risk. Forest Ecology and Management, 211, 150-165. http://dx.doi.org/10.1016/j.foreco.2005.02.014

Wahlenberg, W. G. (1946). Longleaf Pine: Its Use, Ecology, Regeneration, Protection, Growth, and Management. Washington DC: Charles Lathrop Pack Forestry Foundation. 
Scientific Research Publishing (SCIRP) is one of the largest Open Access journal publishers. It is currently publishing more than 200 open access, online, peer-reviewed journals covering a wide range of academic disciplines. SCIRP serves the worldwide academic communities and contributes to the progress and application of science with its publication.

Other selected journals from SCIRP are listed as below. Submit your manuscript to us via either submit@scirp.org or Online Submission Portal.
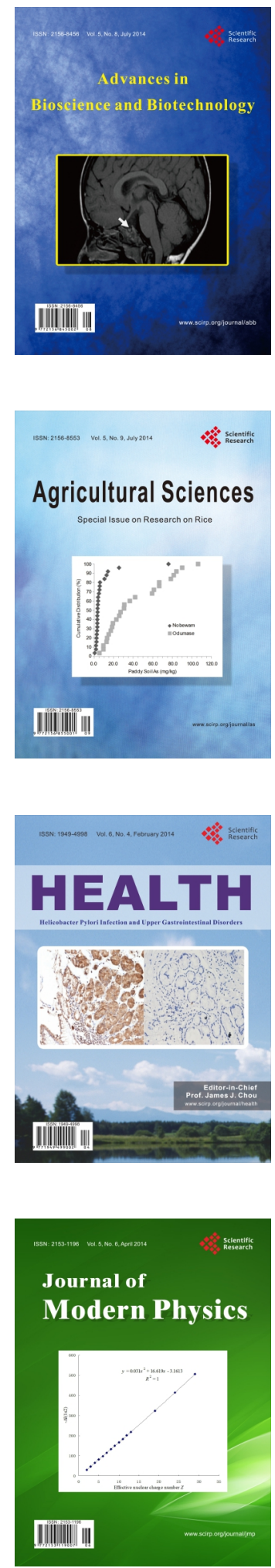
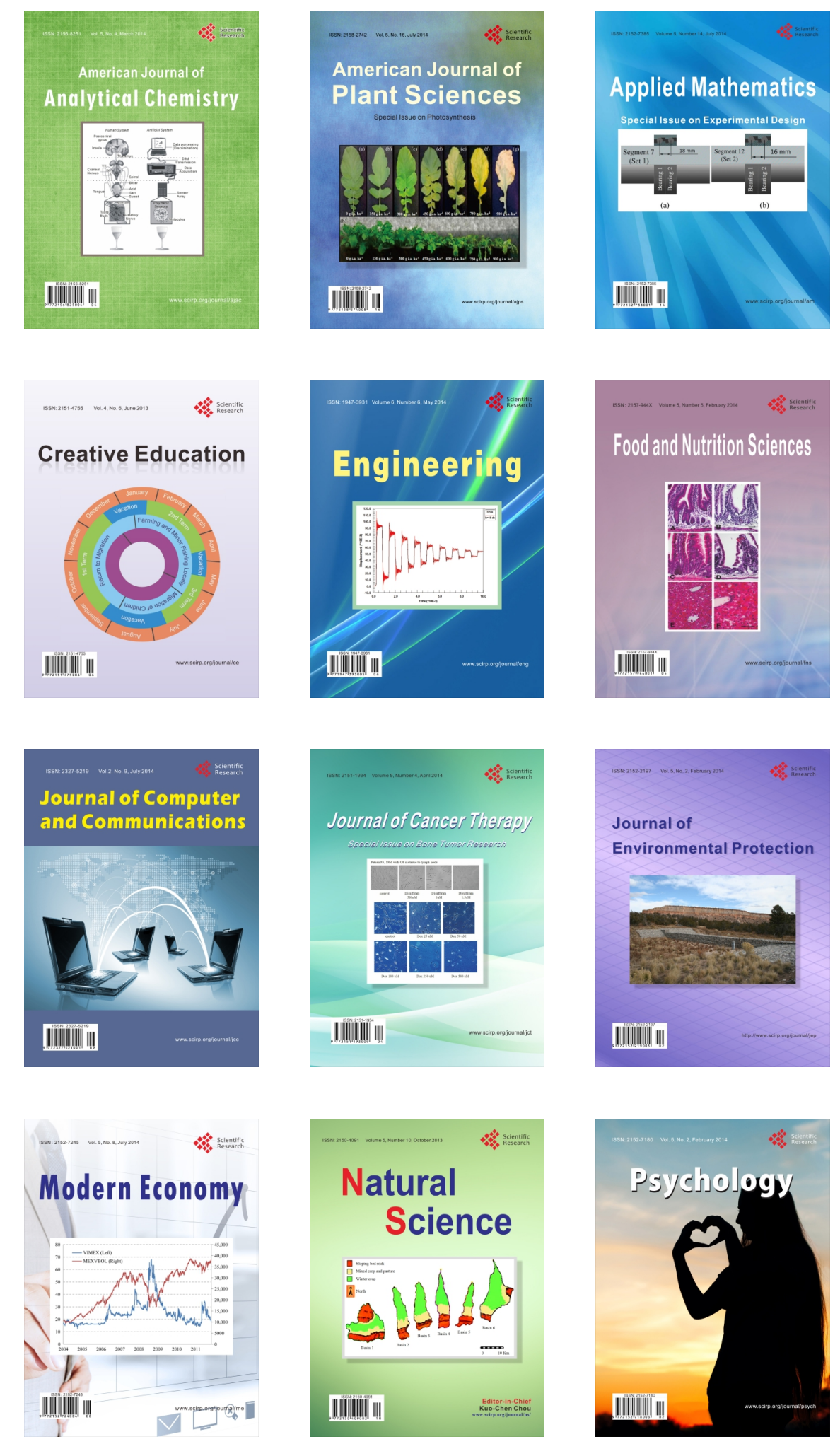